\title{
Рівень прозапальних цитокінів у сироватці крові хворих на цүкровий діабет 1-го та 2-го типів із діабетичними артропатіями
}

\section{В.Л. Орленко}

ДУ «ннститут ендокринології та обміну речовин ім. В.П. Комісаренка НАМН України»

\begin{abstract}
Резюме. Ураження суглобів за цукрового діабету (ЦД) є поширеним ускладненням і пов'язано з виникненням дегенеративно-дистрофічних змін у навколосуглобових структурах. Мета роботи - вивчити рівень прозапальних цитокінів у хворих із діабетичною артропатією та їх можливий вплив на розвиток цього ускладнення. Матеріал і методи. Обстежено 1178 пацієнтів, яких розподілили на групи залежно від типу діабету, наявності та ступеня діабетичної артропатії. Рівні цитокінів у сироватці крові визначали імуноферментним методом. Результати. У пацієнтів із діабетичною артропатією вірогідно підвищено рівні ЧНП- $\alpha$ (за ЦД1 - на 44,5\%, за ЦД2 — на 42,9\%). Виявлено прямий кореляційний зв'язок між ступенем ураження суглобів і рівнями ЧНП- $\alpha$ та ІЛ-6. Для ІЛ-1, S IЛ-6R таких зв'язків не виявлено. Висновки. Ризик розвитку артропатії за ЦД1 зі збільшенням рівня ЧнП- $\alpha$ збільшується в 1,7 раза, зі збільшенням показника ІЛ-6 - в 1,5 раза, за ЦД2 - в 1,8 раза та 1,3 раза відповідно. ЧНП- $\alpha$ та ІЛ-6 можуть бути маркерами наявності та прогресування артропатії у хворих на цукровий діабет.
\end{abstract}

Ключові слова: цукровий діабет, діабетична артропатія, суглоби, хондроцити, цитокіни.

Цукровий діабет (ЦД) наразі залишається однією 3 найважливіших медико-соціальних проблем сучасності у зв'язку з прогресуючим підвищенням захворюваності та інвалідиза-

* Адреса для листування (Correspondence): ДУ «Інститут ендокринології та обміну речовин ім. В.П. Комісаренка НАМН України», вул. Вишгородська, 69, м. Київ, 04114 Україна. E-mail: zdovado@ukr.net

(с) В.Л. Орленко ції зі щорічним накопиченням його тяжких ускладнених форм. Сьогодні в Україні зареєстровано понад 1 млн хворих на ЦД. Фахівці вважають, що цей показник є лише «верхівкою айсберга», реальна кількість таких хворих перевищує 3-4 млн. Оскільки кількість хворих на ЦД кожні 10-15 років подвоюється, можна 
говорити про глобальну епідемію цього захворювання [1]. Зі збільшенням тривалості життя хворих на Цд на перший план виступає нова, надзвичайно важлива проблема - наростання тяжкості пізніх ускладнень захворювання з ураженням практично всіх органів і систем. Не є виключенням і ураження кістково-суглобової системи в пацієнтів із ЦД, поширеність якого, за даними різних авторів, становить від $10 \%$ до 77,8\% [2-4], причому ураження суглобів виявляється в $58 \%$ хворих на ЦД 1-го типу (ЦД1) та у 24\% хворих на ЦД 2-го типу (ЦД2). Проте проведено лише фрагментарні дослідження з питань розвитку, клініки та діагностики діабетичних артропатій.

Ураження суглобів у хворих на ЦД пов'язано 3 виникненням дегенеративно-дистрофічних змін у навколосуглобових структурах, судинах і кісткових тканинах [5]. На тлі ЦД закладаються біохімічні передумови формування клінічної картини ураження суглобів [6].

Єдиним енергетичним субстратом для хондроцитів на тлі виключно анаеробного метаболізму є глюкоза, вміст якої в хондроцитах значно нижчий, ніж у синовіальній рідині та плазмі. Доправлення глюкози в хондроцити здійснюється білками-транспортерами GLUT1 i GLUT3 без участі інсуліну [7]. Недостатне надходження глюкози до хондроцитів, у тому числі за ЦД, призводить до зниження інтенсивності синтетичних процесів і первинної дегенерації хрящової тканини. Водночас хронічна гіперглікемія за ЦД2 неминуче веде до підвищення концентрації глюкози в синовіальній рідині, зв'язках і капсулі суглоба, що зумовлює прояви остеоартрозу через активацію поліолового шляху метаболізму глюкози та неферментативного глікування білків $[8,9]$. Формування кінцевих продуктів глікування (AGEs), у свою чергу, стимулює хондроцити та синовіоцити виробляти продегенеративні (деструктивні) та прозапальні медіатори й змінювати якість субхондральної кісткової тканини [10]. Нейротоксичність гіперглікемії призводить до нервово-м'язової недостатності, що також обтяжує ураження суглобів, призводячи до дестабілізації суглоба та поглиблення дегенеративно-дистрофічних змін у ньому [11].

Для діабетичних артропатій характерно синовіальне запалення, коли виявляється збільшення експресії прозапальних медіаторів і катаболізму матриксу суглобового хряща. Синовіїт активує сенсорні нервові волокна, викликає біль і нейрогенне запалення $[12,13]$. Тобто, формується хронічне запальне захворювання, де переважну роль відіграє дисбаланс цитокінів (інтерлейкінів (IЛ) -1, -6, -17, чинника некрозу пухлин $\alpha$ (ЧНП- $\alpha)$. За цих умов хондроцити експресують рецептори для ІЛ-1, що підвищує їх чутливість до цього цитокіну [14]. Роль ІЛ-1 полягає в його впливі на плазміноген, що сприяє перетворенню останнього на активний плазмін, який, у свою чергу, переводить неактивні про-металопротеази в активну форму, посилюючи деградацію позаклітинного матриксу. Катаболічна дія IЛ-1 проявляється в його здатності стимулювати вироблення хондроцітами та синовіоцитами оксиду азоту (NO), який ушкоджує позаклітинний матрикс. Крім того, NO, знижуючи концентрацію антагоніста рецептора IЛ-1, сам активує IЛ-1 і впливає на апоптоз хондроци-

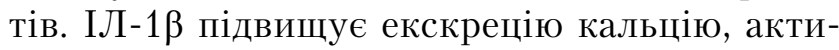
вує остеобласти, що призводить до зниження інтенсивності формування кісткової тканини. Зменшення під його впливом концентрації остеокальцину провокує руйнування субхондральної кістки $[15,16]$. Також спостерігається гіперекспресія ферменту циклооксигенази-2, який індукує синтез простагландинів, що беруть участь у розвитку запалення. $€$ підстави вважати, що прозапальні цитокіни можуть продукуватися хондроцитами або клітинами навколишніх тканин навіть за відсутності явного запалення, причому саме ЦД ініціює підвищення активності цих цитокінів [17]. Так, експресію ІЛ-1 і ЧНП- $\alpha$ відзначено в субхондральній кістці, хрящі та синовіальній оболонці суглобів без клінічних ознак запалення. Відомо, що ЧНП- $\alpha$ має рецептори на хондроцитах, є активатором запалення та тканинного пошкодження за захворювань суглобів, стимулює синтез простагландинів, чинника активації тромбоцитів, супероксидних радикалів, металопротеаз, індукує синтез інших прозапальних цитокінів (ІЛ-1, -6, -8 тощо). ЧНП- $\alpha$ стимулює проліферацію фібробластів і гальмує синтез колагену та протеогліканів. Описані механізми впливу ЧНП- $\alpha$ на компоненти гомеостазу, запалення й опорно-рухового апарату можуть підтримувати дегенера- 
тивні та запальні процеси в суглобах [15, 17]. В осіб похилого віку з ожирінням і болем у колінних суглобах за спроби зниження маси тіла виявлено зниження вмісту розчинного рецептора ЧНП- $\alpha$ паралельно 3 втратою маси тіла [18].

У хворих із патологією суглобів на тлі Цд також встановлено високий вміст IЛ-6, надто на тлі ожиріння. Встановлено, що ІЛ-6 впливає на резорбцію кісткової тканини, вивільнення матриксних металопротеаз, гальмує синтез протеогліканів і колагену хондроцитами [18].

Отже, прозапальні цитокіни порушують гомеостаз позаклітинного матриксу суглобового хряща, провокують збільшення вмісту супероксидних радикалів, синтезу металопротеаз і гальмування синтезу їх інгібіторів, що в кінцевому результаті призводить до дегенерації хряща та розвитку запально-дегенеративних процесів у суглобах на тлі ЦД. У патогенезі ураження суглобів задіяно широке коло медіаторів запалення, вплив яких поширюється не лише на хрящ, але й на синовіальну оболонку, субхондральну кістку, зв’язковий апарат, призводячи до розвитку синовіїту, періоститу, тендиніту.

Метою даного дослідження було вивчення рівнів ЧНП- $\alpha$, IЛ-1 $\alpha$, рецепторів до S IJ-6R y хворих із діабетичною артропатією та їх можливого впливу на розвиток цього ускладнення.

\section{Матеріал і методи}

У дослідженні взяли участь 118 пацієнтів (39 чоловіків і 79 жінок), які перебували на лікуванні в ДУ «Інститут ендокринології та обміну речовин ім. В.П. Комісаренка НАМН України». Із них у 61 пацієнта діагностовано ЦД1 (23 чоловіки та 38 жінок), у 57 - ЦД2 (16 чоловіків і 41 жінка). Жінки переважали в обох групах $(\mathrm{p}<0,05)$, проте відмінності між групами із ЦД за статтю були несуттєвими $\left(\chi^{2}=1,2 ; \mathrm{p}=0,26\right)$.

У таблиці 1 наведено характеристики вибірки за віком, тривалістю ЦД та індексом маси тіла (IMT). Середні вік та IMT пацієнтів із ЦД1 були значуще нижчими, ніж у хворих на ЦД2, зокрема IMT на 23,0\% ( $\mathrm{t}=13,2 ; \mathrm{p}=0,001)$. Тривалість ЦД була більшою в пацієнтів із
Таблиця 1. Характеристика вибірки обстежених пацієнтів

\begin{tabular}{|c|c|c|c|c|c|c|c|c|c|c|}
\hline \multirow[t]{2}{*}{ Групи } & \multirow[t]{2}{*}{ n (\%) } & \multicolumn{3}{|l|}{ Вік } & \multicolumn{3}{|c|}{ Тривалість ЦД } & \multicolumn{3}{|l|}{ IMT } \\
\hline & & $M$ & $\sigma$ & $\mathrm{m}$ & $M$ & $\sigma$ & $\mathrm{m}$ & $M$ & $\sigma$ & $\mathrm{m}$ \\
\hline ЦД1 & 61 & 39,2 & 11,0 & 1,4 & 19,4 & 10,2 & 1,3 & 25,6 & 3,1 & 0,4 \\
\hline Чоловіки & $\begin{array}{l}23 \\
(37,7)\end{array}$ & 40,5 & 11,4 & 2,4 & 19,2 & 8,4 & 1,8 & 26,1 & 1,8 & 0,4 \\
\hline Жінки & $\begin{array}{l}38 \\
(62,3)\end{array}$ & 38,4 & 10,9 & 1,8 & 19,5 & 11,2 & 1,8 & 25,4 & 3,7 & 0,6 \\
\hline ЦД2 & 57 & 63,6 & 9,1 & 1,2 & 15,7 & 7,0 & 0,9 & 33,3 & 3,6 & 0,5 \\
\hline Чоловіки & $\begin{array}{l}16 \\
(28,1)\end{array}$ & 62,8 & 13,2 & 3,3 & 15,9 & 8,5 & 2,1 & 32,7 & 2,1 & 0,5 \\
\hline Жінки & $\begin{array}{l}41 \\
(71,9)\end{array}$ & 64,0 & 7,1 & 1,1 & 15,7 & 6,5 & 1,0 & 33,5 & 4,0 & 0,6 \\
\hline $\begin{array}{l}\text { Обидві } \\
\text { групи }\end{array}$ & 118 & 51,0 & 15,9 & 1,5 & 17,6 & 9,0 & 0,8 & 29,3 & 5,1 & 0,5 \\
\hline \multicolumn{11}{|c|}{ Статистика } \\
\hline \multicolumn{2}{|l|}{ Тип ЦД } & \multicolumn{3}{|c|}{$\begin{array}{l}t=13,2 ; \\
p=0,001\end{array}$} & \multicolumn{3}{|c|}{$\begin{array}{l}t=2,3 ; \\
p=0,023\end{array}$} & \multicolumn{3}{|c|}{$\begin{array}{l}t=12,4 \\
p=0,001\end{array}$} \\
\hline \multicolumn{2}{|c|}{$\begin{array}{l}\text { ЦД1 чоловіки/ } \\
\text { жінки }\end{array}$} & \multicolumn{3}{|c|}{$\begin{array}{l}t=0,7 \\
p=0,471\end{array}$} & \multicolumn{3}{|c|}{$t=0,10 ; p=0,918$} & \multicolumn{3}{|c|}{$\begin{array}{l}t=0.9 \\
p=0,325\end{array}$} \\
\hline \multicolumn{2}{|c|}{$\begin{array}{l}\text { ЦД2 чоловіки/ } \\
\text { жінки }\end{array}$} & \multicolumn{3}{|c|}{$\begin{array}{l}t=0,4 ; \\
p=0,723\end{array}$} & \multicolumn{3}{|c|}{$t=0,09 ; p=0,928$} & \multicolumn{3}{|c|}{$\begin{array}{l}t=1,0 ; \\
p=0,322\end{array}$} \\
\hline
\end{tabular}

ЦД1 на 19,0\% (t=2,3; p=0,023). Відмінностей за статевим складом не виявлено ( $\mathrm{p}>0,3)$.

Артропатію виявлено в 90 (77,2\%) пацієнтів, у решти 28 (22,8\%) хворих на ЦД це ускладнення було відсутнє.

Наявність і ступінь діабетичної артропатії оцінювали за методикою А. Rosenbloom [19], ступінь нефропатії - за класифікацією C.F. Mogenson (1992), ретинопатії - за класифікацією Е. Kohner, M. Porta.

Вміст глюкози в крові визначали глюкозооксидазним методом. Нормальними значеннями вважали 3,3-5,5 ммоль/л. Ступінь компенсації вуглеводного обміну оцінювали за рівнем глікованого гемоглобіну (HbA1c), який визначали калориметричним методом із тіобарбітуровою кислотою. Компенсацію ЦД реєстрували за рівня НbА1с до 7\%. У комплекс досліджень також входили традиційні клінічні тести (біохімічний аналіз крові, загальний аналіз крові, сечі, визначення добової протеїнурії, К, Са загального та іонізованого, глікемічний профіль). Функцію нирок оцінювали за ШКФ за формулою СКD ЕРІ. Вміст ІЛ-6, ЧНП- $\alpha$, ІЛ-1 і рецепторів до S IJ-6R у сироватці крові визначали імуноферментним методом (ELISA) за допомогою набору реагентів Diaclone (Франція) та планшетного імуноферментного аналізатора Stat fax 3200 (США). 
Оригінальні дослідження

Статистичну обробку отриманих даних проводили за допомогою методів варіаційної статистики стандартного пакета для статистичних підрахунків Statistica 5.0 Microsoft OffiseExel 2003. Наведено середні величини (M), середнє квадратичне відхилення (SD), стандартні помилки середньої величини (m). Для порівняння середніх абсолютних величин у різних групах застосовували t-критерій Стьюдента. Різницю вважали вірогідною за $\mathrm{p} \leq 0,05$. Для аналізу також використано кореляційний, дисперсійний однофакторний, множинний регресійний аналізи, дискримінантну статистику.

\section{Результати та їх обговорення}

У табл. 2 наведено розподіл пацієнтів за типом ЦД, статтю та наявністю артропатії. Частота артропатії практично не різнилася залежно від типу ЦД ( $\mathrm{t}=0,23 ; \mathrm{p}>0,1)$. У даній вибірці не підтвердився висновок про вищі шанси розвитку артропатії в жінок із ЦД2, ніж у чоловіків $(\mathrm{OR}=2,91$; ДI=0,80-10,68, $\mathrm{p}=0,106)$. За ЦД1 шанси на розвиток артропатії в чоловіків і жінок також виявилися рівними $(\mathrm{OR}=1,14 ;$ ДI=0,34-3,75, $\mathrm{p}=0,833)$.

У групі із ЦД1 ураження нирок мали 35 пацієнтів, у групі із ЦД2 - 38. У табл. 3 наведено

Таблиця 2. Розподіл пацієнтів за типом ЦД, статтю та наявністю артропатії

\begin{tabular}{|c|c|c|c|c|}
\hline \multirow[t]{2}{*}{ Група } & \multirow[t]{2}{*}{ Стать } & \multirow[t]{2}{*}{$n / \%$} & \multicolumn{2}{|c|}{ Артропатія } \\
\hline & & & відсутня & наявна \\
\hline \multirow{6}{*}{$\begin{array}{l}\text { ЦД1 } \\
\left(x^{2}=0,05 ;\right. \\
p=0,833)\end{array}$} & чоловіки & $\mathrm{n}$ & 6 & 17 \\
\hline & & $\%$ & $26,1 \pm 9,2$ & $73,9 \pm 9,2$ \\
\hline & жінки & $n$ & 9 & 29 \\
\hline & & $\%$ & $23,7 \pm 6,9$ & $76,3 \pm 6,9$ \\
\hline & загалом & $n$ & 15 & 46 \\
\hline & & $\%$ & $24,6 \pm 5,5$ & $75,4 \pm 5,5$ \\
\hline \multirow{6}{*}{$\begin{array}{l}\text { ЦД2 } \\
\left(x^{2}=2,73 ;\right. \\
p=0,099)\end{array}$} & чоловіки & $\mathrm{n}$ & 6 & 10 \\
\hline & & $\%$ & $37,5 \pm 12,1$ & $62,5 \pm 12,1$ \\
\hline & жінки & $\mathrm{n}$ & 7 & 34 \\
\hline & & $\%$ & $17,1 \pm 5,9$ & $82,9 \pm 5,9$ \\
\hline & загалом & $\mathrm{n}$ & 13 & 44 \\
\hline & & $\%$ & $22,8 \pm 5,6$ & $77,2 \pm 5,6$ \\
\hline \multirow{6}{*}{$\begin{array}{l}\text { Обидві групи } \\
\left(x^{2}=1,59 ;\right. \\
p=0,207)\end{array}$} & чоловіки & $n$ & 12 & 27 \\
\hline & & $\%$ & $30,8 \pm 7,4$ & $69,2 \pm 7,4$ \\
\hline & жінки & $\mathrm{n}$ & 16 & 63 \\
\hline & & $\%$ & $20,3 \pm 4,5$ & $79,8 \pm 4,5$ \\
\hline & загалом & $\mathrm{n}$ & 28 & 90 \\
\hline & & $\%$ & $23,7 \pm 3,9$ & $76,3 \pm 3,9$ \\
\hline
\end{tabular}

частоту артропатії серед обстежених залежно від наявності ураження нирок. Взаємозв’язок ураження нирок і розвитку артропатії підтверджено лише для пацієнтів із Цд2. Шанси на розвиток артропатії в пацієнтів із ЦД2 та ураженням нирок виявилися вищими в 5,2 раза, ніж у пацієнтів без цього ускладнення $(\mathrm{OR}=5,17 ;$ ДI=1,32-20,22, $\mathrm{p}=0,018)$. Для пацієнтів із ЦД1 ці шанси були рівними $(\mathrm{OR}=0,31$; ДI=0,06-1,61, $\mathrm{p}=0,163)$.

У групі із ЦД2 рівень глюкози в крові натще та ШКФ були вірогідно нижчими, ніж у групі із ЦД1 (табл. 4). Вміст білка в сечі був вищим

Таблиця 3. Розподіл пацієнтів за типом ЦД і частота артропатії залежно від наявності ураження нирок

\begin{tabular}{lllll}
\hline Група & Ураження & $\mathbf{n} /$ & \multicolumn{2}{l}{ Артропатія } \\
\cline { 5 - 5 } & нирок & $\%$ & відсутня & наявна \\
\hline ЦД1 & відсутн $\epsilon$ & $\mathrm{n}$ & 2 & 13 \\
$\left(\mathrm{X}^{2}=2,09 ;\right.$ & & $\%$ & $13,3 \pm 8,8$ & $86,7 \pm 8,8$ \\
$\mathrm{p}=0,148)$ & наявне & $\mathrm{n}$ & 11 & 22 \\
& & $\%$ & $33,3 \pm 8,2$ & $66,7 \pm 8,2$ \\
& \multirow{2}{*}{ загалом } & $\mathrm{n}$ & 13 & 35 \\
& & $\%$ & $72,9 \pm 6,4$ & $72,9 \pm 6,4$ \\
ЦД2 & Відсутн $\epsilon$ & $\mathrm{n}$ & 7 & 6 \\
$\left(\mathrm{X}^{2}=3,92 ;\right.$ & & $\%$ & $53,8 \pm 13,8$ & $46,2 \pm 13,8$ \\
$\mathrm{p}=0,048)$ & наявне & $\mathrm{n}$ & 7 & 31 \\
& & $\%$ & $18,4 \pm 6,3$ & $81,6 \pm 6,3$ \\
& \multirow{2}{*}{ загалом } & $\mathrm{n}$ & 13 & 38 \\
& & $\%$ & $25,5 \pm 6,1$ & $74,5 \pm 6,1$ \\
\hline
\end{tabular}

таблиця 4. Лабораторні показники в обстежених залежно від типу ЦД (t-test)

\begin{tabular}{|c|c|c|c|c|c|c|c|c|}
\hline \multirow[t]{2}{*}{ Показник } & \multicolumn{3}{|l|}{ ЦД1 } & \multicolumn{3}{|l|}{ цД2 } & \multirow[t]{2}{*}{$t$} & \multirow[t]{2}{*}{$p$} \\
\hline & $\bar{M}$ & $\mathbf{M}$ & $\sigma$ & $M$ & $M$ & $\Sigma$ & & \\
\hline $\mathrm{HbA} 1 \mathrm{c}, \%$ & 8,40 & 0,20 & 1,59 & 8,24 & 0,15 & 1,15 & 0,6 & 0,531 \\
\hline $\begin{array}{l}\text { Глікемія } \\
\text { натще, } \\
\text { ммоль/л }\end{array}$ & 9,89 & 0,51 & 3,98 & 8,03 & 0,28 & 2,11 & 3,2 & 0,002 \\
\hline $\begin{array}{l}\text { Глікемія після } \\
\text { їжі, ммоль/л }\end{array}$ & 11,44 & 0,59 & 4,62 & 10,39 & 0,41 & 3,06 & 1,5 & 0,149 \\
\hline $\begin{array}{l}\text { Холестерин, } \\
\text { ммоль/л }\end{array}$ & 5,46 & 0,16 & 1,24 & 5,85 & 0,23 & 1,72 & 1,4 & 0,169 \\
\hline $\begin{array}{l}\text { Креатинін, } \\
\text { ммоль/л }\end{array}$ & 93,56 & 3,69 & 28,85 & 97,56 & 3,81 & 28,75 & 0,8 & 0,452 \\
\hline ШКФ, мл/хв & 107,57 & 6,57 & 51,31 & 90,62 & 5,43 & 40,98 & 2,0 & 0,049 \\
\hline $\begin{array}{l}\text { Білок у сечі, } \\
\text { г/л }\end{array}$ & 0,08 & 0,02 & 0,13 & 0,15 & 0,03 & 0,25 & 2,0 & 0,047 \\
\hline $\begin{array}{l}\text { Кальцій, } \\
\text { ммоль/л }\end{array}$ & 2,29 & 0,07 & 0,56 & 2,16 & 0,03 & 0,25 & 1,6 & 0,115 \\
\hline $\begin{array}{l}\text { Калій, } \\
\text { ммоль/л }\end{array}$ & 4,45 & 0,06 & 0,37 & 4,41 & 0,05 & 0,31 & 0,5 & 0,644 \\
\hline $\begin{array}{l}\text { Загальний } \\
\text { білок, г/л }\end{array}$ & 69,25 & 0,82 & 6,42 & 69,58 & 0,60 & 4,54 & 0,3 & 0,749 \\
\hline
\end{tabular}


у пацієнтів із ЦД2. За іншими лабораторними показниками статистичних відмінностей не виявлено.

Порівняння середніх лабораторних показників у пацієнтів з артропатією та без неї залежно від типу ЦД виявило підвищення ШКФ у пацієнтів із ЦД1 та артропатією. За іншими показниками статистичних відмінностей не визначено. Підвищення ШКФ може свідчити про компенсаторну реакцію нирок на початкових стадіях розвитку нефропатії, а, як відомо, артропатія є пізнім ускладненням ЦД і частіше розвивається у хворих на ЦД на тлі інших ускладнень.

Проведення двофакторного дисперсійного аналізу з чинниками «ЦД» і «стать» не виявило відмінностей у середніх рівнях цитокінів (табл. 5).

За допомогою логіт-регресійного аналізу встановлено, що за ЦД і наявності артропатії рівні ЧНП- $\alpha$ та ІЛ-6 були вірогідно вищими, ніж за відсутності артропатії.

Результати логіт-регресійного аналізу із залежною змінною ЧНП- $\alpha$ і наявністю/відсутністю артропатії як незалежною змінною були вірогідними як для групи із ЦД1 $\left(\chi^{2}=27,2 ; \mathrm{p}<0,001\right)$, так і для групи із ЦД2 $\left(\chi^{2}=26,8 ; \mathrm{p}<0,001\right)$. Чутливість моделі для групи із ЦД1 становила 53,3\%, специфічність - 93,0\%, відповідні показники для групи із ЦД2 - 76,9\% і 90,5\%.

Шанси на виявлення артропатії з підвищенням рівня ЧНП- $\alpha$ за ЦД1 зростали в 1,7 раза ( $\mathrm{OR}=1,70 ;$ ДI $1,19-2,44)$, за ЦД2 - в 1,8 раза (OR=1,78; ДІ 1,21-2,61).

Результати логіт-регресійного аналізу із залежною змінною ІЛ-6 і наявністю/відсутністю артропатії як незалежної змінної були також вірогідними як для групи із ЦД1 $\left(\chi^{2}=23,2\right.$; $\mathrm{p}<0,001)$, так і для групи із ЦД2 $\left(\chi^{2}=29,6\right.$; $\mathrm{p}<0,001)$. Чутливість моделі для групи із ЦД1 становила 70,0\%, специфічність - 90,6\%. Відповідні показники для групи із ЦД2 $92,3 \%$ i $86,2 \%$.

Шанси на виявлення артропатії 3 підвищенням рівня ІЛ-6 за ЦД1 зростали в 1,5 раза $(\mathrm{OR}=1,47$; ДI $1,08-1,98)$, за ЦД2 в 1,3 раза (OR=1,34; ДI 1,03-1,74).

Вірогідних результатів логіт-регресійного аналізу з показниками IЛ-1, IJ-6R як незалежними змінними та наявністю/відсутністю артропатії як незалежною змінною отримати не вдалося $(\mathrm{p}>0,2)$.

Встановлено різницю середнього рівня ЧНП- $\alpha$ залежно від стадії артропатії ( $\mathrm{F}=37,3$; $\mathrm{p}<0,001$; рис. 1, табл. 6).

У пацієнтів із ЦД1 середній рівень ЧНП- $\alpha$ за наявності артропатії був вищим на 44,5\%, ніж за її відсутності ( $\mathrm{t}=5,2 ; \mathrm{p}<0,001)$, за ЦД2 на $42,9 \%(\mathrm{t}=7,2 ; \mathrm{p}<0,001)$.

За ЦД1 встановлено різницю в показниках ЧНП- $\alpha$ в пацієнтів без артропатії та з артропатією 1-ї стадії (t=3,1; p<0,01), 2-ї та 3-ї стадій

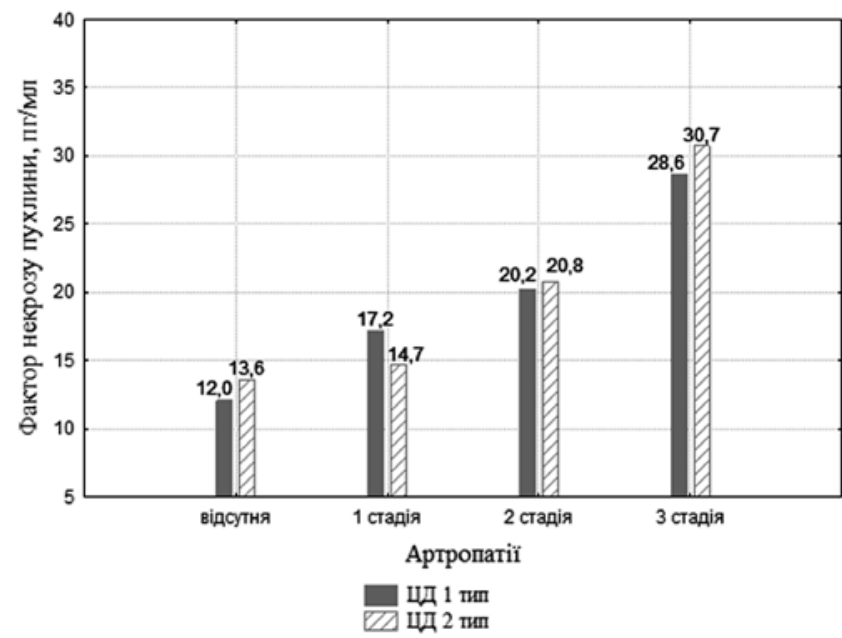

Рис. 1. Показники ЧНП-а (пг/мл) залежно від типу ЦД і стадії артропатії.

Таблиця 5. Показники цитокінів (пг/мл) в обстежених залежно від типу ЦД і статі (двофакторний дисперсійний аналіз)

\begin{tabular}{|c|c|c|c|c|c|c|c|c|c|c|c|c|c|c|c|c|}
\hline \multirow[t]{2}{*}{ Група } & \multicolumn{4}{|c|}{ ЧнП-а } & \multicolumn{4}{|l|}{ ІЛ-6 } & \multicolumn{4}{|c|}{ ІЛ-1a } & \multicolumn{4}{|c|}{ S ІЛ-6R } \\
\hline & $\bar{n}$ & $M$ & $\sigma$ & $M$ & $\mathrm{n}$ & $M$ & $\Sigma$ & $\mathrm{m}$ & $n$ & $M$ & $\sigma$ & $m$ & $\mathrm{n}$ & $M$ & $\sigma$ & $m$ \\
\hline ЦД1 & 60 & 20,2 & 12,4 & 1,6 & 60 & 23,8 & 19,7 & 2,5 & 20 & 12,0 & 3,3 & 0,7 & 20 & 323,7 & 68,9 & 15,4 \\
\hline чоловіки & 23 & 19,7 & 10,2 & 2,1 & 23 & 26,0 & 18,4 & 3,8 & 6 & 11,6 & 2,8 & 1,1 & 6 & 344,5 & 89,4 & 36,5 \\
\hline жінки & 37 & 20,5 & 13,7 & 2,3 & 37 & 22,5 & 20,5 & 3,4 & 14 & 12,2 & 3,6 & 1,0 & 14 & 314,8 & 59,8 & 16,0 \\
\hline ЦД2 & 55 & 24,5 & 17,4 & 2,3 & 55 & 28,6 & 25,2 & 3,4 & 18 & 11,3 & 3,0 & 0,7 & 18 & 358,7 & 64,4 & 15,2 \\
\hline чоловіки & 16 & 23,9 & 23,0 & 5,8 & 16 & 27,3 & 30,2 & 7,5 & 5 & 10,3 & 1,8 & 0,8 & 5 & 373,6 & 79,4 & 35,5 \\
\hline жінки & 39 & 24,7 & 14,9 & 2,4 & 39 & 29,2 & 23,2 & 3,7 & 13 & 11,7 & 3,3 & 0,9 & 13 & 353,0 & 60,4 & 16,8 \\
\hline$F$ & 0,00 & & & & 0,36 & & & & 0,11 & & & & 0,04 & & & \\
\hline 3 & 1,00 & & & & 0,549 & & & & 0,747 & & & & 0,852 & & & \\
\hline
\end{tabular}


Оригінальні дослідження

таблиця 6. Рівень ЧНП-а (пг/мл) у хворих із різними стадіями артропатій

\begin{tabular}{lllllll}
\hline Група & $\mathbf{N}$ & Артропатія & $\mathbf{M}$ & $\mathbf{M}$ & $\mathbf{- 9 5 , 0 0 \%}$ & $\mathbf{+ 9 5 , 0 0 \%}$ \\
\hline ЦД1 & 15 & відсутня & 12,05 & 1,61 & 8,85 & 15,24 \\
& 12 & 1-а стадія & 17,16 & 1,80 & 13,59 & 20,73 \\
& 19 & 2-а стадія & 20,21 & 1,43 & 17,37 & 23,05 \\
\multirow{4}{*}{ ЦД2 } & 12 & 3-я стадія & 28,63 & 1,80 & 25,05 & 32,20 \\
& 13 & відсутня & 13,59 & 1,73 & 10,16 & 17,02 \\
& 7 & 1-а стадія & 14,70 & 2,36 & 10,02 & 19,38 \\
& 18 & 2-а стадія & 20,78 & 1,47 & 17,86 & 23,69 \\
& 17 & 3-я стадія & 30,72 & 1,51 & 27,72 & 33,72 \\
\hline
\end{tabular}

$(\mathrm{t}=2,4 ; \mathrm{p}<0,05)$. Між рівнями ЧНП- $\alpha$ за артропатії 1-ї та 2-ї стадій вірогідної різниці не виявлено $(\mathrm{t}=1,7 ; \mathrm{p}=0,10)$.

За ЦД2 встановлено відмінності середніх показників ЧНП- $\alpha$ в пацієнтів 3 артропатією 1-ї та 2-ї стадій $(\mathrm{t}=3,6 ; \mathrm{p}<0,01)$ та з артропатією 2-ї та 3-ї стадій $(\mathrm{t}=4,4 ; \mathrm{p}<0,001)$. Між рівнями ЧНП- $\alpha$ за відсутності артропатії та за артропатії 1-ї стадії вірогідних відмінностей не виявлено $(\mathrm{t}=0,96 ; \mathrm{p}=0,36)$.

Встановлено відмінності середнього рівня показника ІЛ-6 залежно від стадії артропатії ( $\mathrm{F}=28,2 ; \mathrm{p}<0,001)$ (рис. 2).

У пацієнтів із ЦД1 середній рівень ІЛ-6 (табл. 7) за наявності артропатії був більшим на 52,1\%, ніж заїі відсутності $(\mathrm{t}=5,6$; $<<0,001)$, у хворих на ЦД2 - на $64,4 \%(\mathrm{t}=7,3 ; \mathrm{p}<0,001)$. За ЦД1 встановлено різницю середніх показників ІЛ-6 у пацієнтів без артропатії та з іiі 1 -ю стадією $(\mathrm{t}=3,4 ; \mathrm{p}<0,05)$ та 3 артропатією 1-ї та 3-ї стадій $(\mathrm{t}=2,8 ; \mathrm{p}<0,05)$. Між рівнями ІЛ-6 у хворих з артропатією 1-ї та 2-ї стадій, а також 2-ї та 3-ї стадій вірогідних відмінностей не виявлено $(\mathrm{t}=1,8 ; \mathrm{p}=0,07 \mathrm{it}=1,9 ; \mathrm{p}=0,08)$.

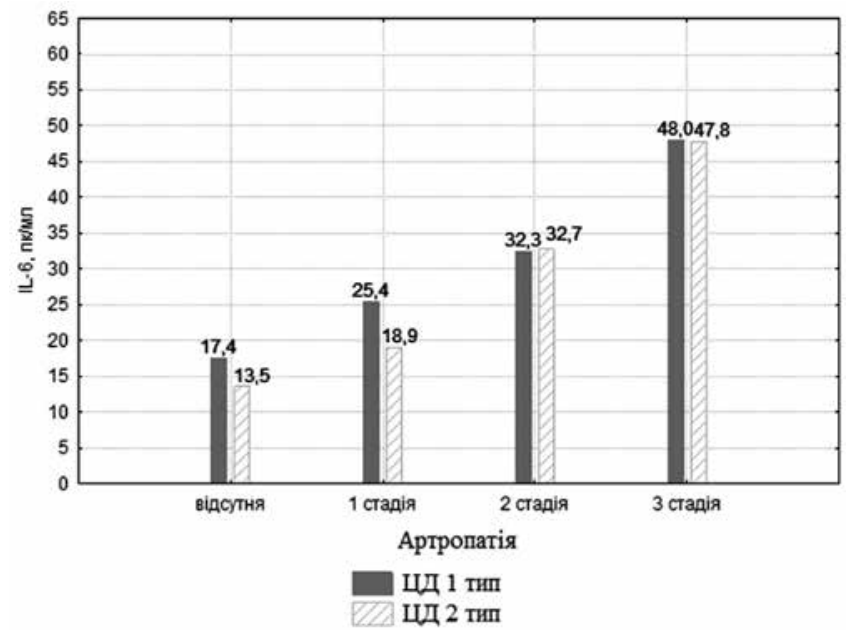

Рис. 2. Рівень ІЛ-6 залежно від типу ЦД і стадії артропатії (пг/мл).
За ЦД2 виявлено різницю в показниках IЛ-6 у пацієнтів без артропатії та 3 iï 1-ю стаді$\epsilon ю(\mathrm{t}=2,6 ; \mathrm{p}<0,05), 3$ 1-ю та 2-ю стадіями $(\mathrm{t}=3,9 ; \mathrm{p}<0,01)$ і з 2 -ю та 3 -ю стадіями $(\mathrm{t}=3,4$; $\mathrm{p}<0,01)$.

Для показників IЛ-1 та S IJ-6R різниці залежно від стадії артропатії не виявлено ( $\mathrm{p}>0,4$; рис. 3,4 , табл. 8,9$)$.

Таблиця 7. Рівень ІЛ-б у хворих із різними стадіями артропатій

\begin{tabular}{|c|c|c|c|c|c|c|}
\hline цд & $\mathbf{n}$ & Артропатія & Середнє & $\begin{array}{l}\text { Стандартна } \\
\text { похибка }\end{array}$ & $\begin{array}{l}-95,00 \\
\%\end{array}$ & $\begin{array}{l}+95,00 \\
\%\end{array}$ \\
\hline \multirow[t]{4}{*}{$1-\breve{n}$} & 10 & відсутня & 17,44 & 3,95 & 9,57 & 25,31 \\
\hline & 6 & 1-а стадія & 25,43 & 5,10 & 15,27 & 35,60 \\
\hline & 15 & 2-а стадія & 32,33 & 3,23 & 25,90 & 38,76 \\
\hline & 11 & 3-я стадія & 47,98 & 3,77 & 40,47 & 55,48 \\
\hline \multirow[t]{4}{*}{$2-\breve{n}$} & 13 & відсутня & 13,54 & 3,47 & 6,64 & 20,45 \\
\hline & 4 & 1-а стадія & 18,93 & 6,25 & 6,48 & 31,37 \\
\hline & 11 & 2-а стадія & 32,73 & 3,77 & 25,22 & 40,23 \\
\hline & 14 & 3-я стадія & 47,76 & 3,34 & 41,10 & 54,41 \\
\hline
\end{tabular}

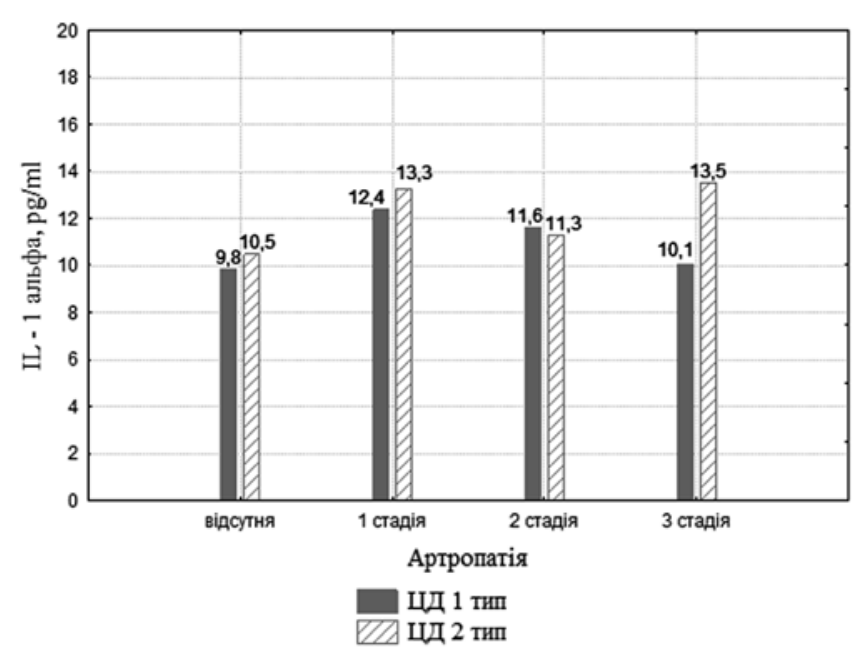

Рис. 3. Рівень ІЛ-1 залежно від типу ЦД і стадії артропатії (пг/мл).

таблиця 8. Рівень ІЛ-1 у хворих на ЦД з артропатією різних стадій

\begin{tabular}{|c|c|c|c|c|c|c|}
\hline $\begin{array}{l}\text { Тип } \\
\text { ЦД }\end{array}$ & $\mathbf{n}$ & Артропатія & Середнє & $\begin{array}{l}\text { Стандартна } \\
\text { похибка }\end{array}$ & $\begin{array}{l}-95,00 \\
\%\end{array}$ & $\begin{array}{l}+95,00 \\
\%\end{array}$ \\
\hline \multirow[t]{4}{*}{ 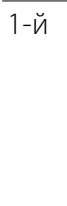 } & 5 & відсутня & 13,57 & 1,50 & 10,52 & 16,62 \\
\hline & 6 & 1-а стадія & 12,37 & 1,37 & 9,58 & 15,15 \\
\hline & 5 & 2-а стадія & 11,62 & 1,50 & 8,57 & 14,67 \\
\hline & 4 & 3-я стадія & 10,06 & 1,67 & 6,65 & 13,47 \\
\hline \multirow[t]{4}{*}{$2-\breve{n}$} & 5 & відсутня & 10,47 & 1,50 & 7,42 & 13,52 \\
\hline & 3 & 1-а стадія & 13,27 & 1,93 & 9,33 & 17,21 \\
\hline & 9 & 2-а стадія & 11,30 & 1,12 & 9,03 & 13,58 \\
\hline & 3 & 3-я стадія & 13,53 & 1,93 & 9,59 & 17,47 \\
\hline
\end{tabular}


Таблиця 9. Рівень S ІЛ-6R у хворих з артропатією різних стадій

\begin{tabular}{|c|c|c|c|c|c|c|}
\hline $\begin{array}{l}\text { Тип } \\
\text { ЦД }\end{array}$ & $\mathbf{N}$ & $\begin{array}{l}\text { Артропа- } \\
\text { тія }\end{array}$ & $\begin{array}{l}\text { Серед- } \\
\mathbf{H \epsilon}\end{array}$ & $\begin{array}{l}\text { Стандартна } \\
\text { похибка }\end{array}$ & $\begin{array}{l}-95,00 \\
\% \\
\end{array}$ & $\begin{array}{l}+95,00 \\
\%\end{array}$ \\
\hline \multirow[t]{4}{*}{$1-\breve{и}$} & 5 & відсутня & 294,6 & 30,8 & 231,6 & 357,6 \\
\hline & 6 & 1-а стадія & 318,5 & 28,2 & 261,0 & 376,0 \\
\hline & 5 & 2-а стадія & 346,6 & 30,8 & 283,6 & 409,6 \\
\hline & 4 & 3-я стадія & 339,3 & 34,5 & 268,8 & 409,7 \\
\hline \multirow[t]{4}{*}{$2-\breve{и}$} & 4 & відсутня & 365,0 & 34,5 & 294,6 & 435,4 \\
\hline & 3 & 1-а стадія & 308,3 & 39,8 & 227,0 & 389,7 \\
\hline & 9 & 2-а стадія & 366,3 & 23,0 & 319,4 & 413,3 \\
\hline & 2 & 3-я стадія & 387,5 & 48,8 & 287,9 & 487,1 \\
\hline
\end{tabular}

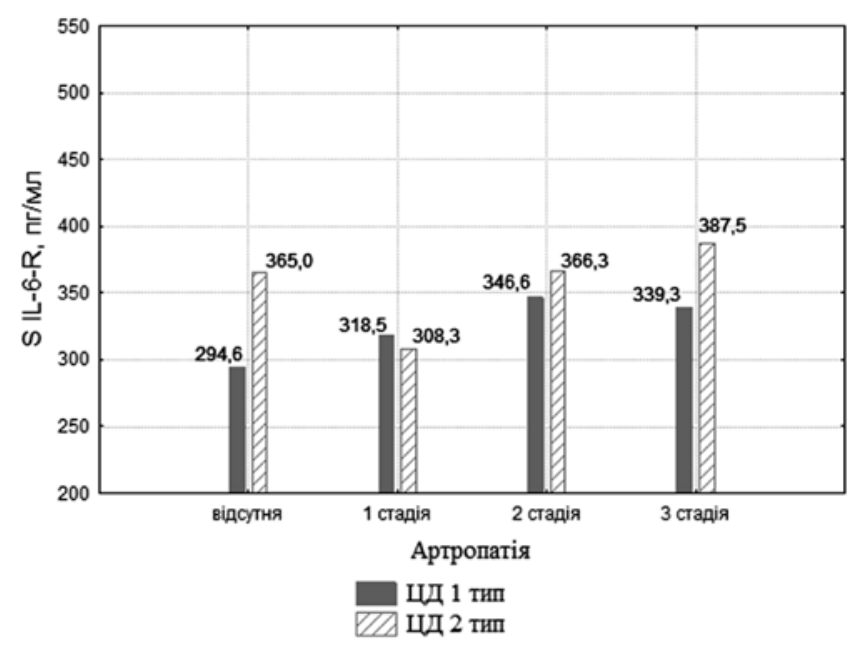

Рис. 4. Рівень S ІЛ-6R залежно від типу ЦД і стадії артропатії (пг/мл).

Отже, за отриманими даними можна вважати, що основними прозапальними цитокінам, які можуть бути маркерами наявності та прогресування артропатії у хворих на цукровий діабет, є ЧНП- $\alpha$ та ІЛ-6.

\section{Висновки}

1. Ризик розвитку артропатії є рівним для жінок і чоловіків, хворих на ЦД1 і ЦД2.

2. Показник ШКФ збільшено в пацієнтів із ЦД1 та артропатією, що може свідчити про компенсаторну реакцію нирок на початкових стадіях розвитку нефропатії. Ризик розвитку артропатії для пацієнтів із ЦД1 не залежить від наявності ураження нирок, а серед хворих на ЦД2 він у 5,2 раза вищий для пацієнтів із цим ускладненням.

3. У пацієнтів із ЦД1 рівень ЧНП- $\alpha$ з артропатією вищий на 44,5\%, ніж за їі відсутності, у хворих на ЦД2 - на 42,9\%. Ризик розвитку артропатії зі збільшенням показника ЧНП- $\alpha$ на тлі ЦД1 зростає в 1,7 раза, за ЦД2 - в 1,8 раза.
4. У пацієнтів із ЦД1 рівень ІЛ-6 з артропатією є вищим на 52,1\%, ніж за іiі відсутності, у хворих на ЦД 2 - на $64,4 \%$. Ризик розвитку артропатії зі збільшенням показника ІЛ-6 за ЦД1 зростає в 1,5 раза, за ЦД2 - в 1,3 раза.

\section{Список використаної літератури}

1. Shikhman AR, Brinson DC, Valbracht J, Lotz MK. Cytokine regulation of facilitated glucose transport in human articular chondrocytes. J Immunol. 2001 Dec; 67(12):7001-8.

2. Shikhman AR, Brinson DC, Lotz MK. Distinct pathways regulate facilitated glucose transport in humanarticular chondrocytes during anabolic and catabolic responses. AJP Endocrinology and Metabolism. $2004 \mathrm{Jul} ; 286(6): 980-5$.

3. Garessus ED, Mutsert R, Visser AW, Rosendaal FR, Kloppenburg M. No association between impaired glucose metabolism and osteoarthritis. Osteoarthritis Cartilage. 2016 Sep;24(9):1541-7.

4. Frey N, Hügle T, Jick SS, Meier CR, Spoendlin J. Type II diabetes mellitus and incident osteoarthritis of the hand: a population-based casecontrol analysis. Osteoarthritis Cartilage. 2016 Sep; 24(9):1535-40.

5. Frey N, Hügle T, Jick SS, Meier CR, Spoendlin J. Hyperlipidaemia and incident osteoarthritis of the hand: a population-based casecontrol study.Osteoarthritis Cartilage. 2017 Jul;25(7):1040-5.

6. Courties A, Sellam J. Osteoarthritis and type 2 diabetes mellitus: what are the links? Diabetes Research and Clinical Practice, Elsevier's 2016, <10.1016/j.diabres.2016.10.021>. <hal01396521>

7. Magnusson K, Hagen KB, Osterås N, Nordsletten L, Natvig B, Haugen IK. Diabetes is associated with increased hand pain in erosive hand osteoarthritis: data from a population-based study. Arthritis Care Res (Hoboken). 2015 Feb; 67(2):187-95.

8. Rasheed Z, Akhtar N, Haqqi TM. Advanced glycation end products induce the expression of interleukin- 6 and interleukin- 8 by receptor for advanced glycation end product-mediated activation of mitogen-activated protein kinases and nuclear factor- $\kappa \mathrm{B}$ in human osteoarthritis chondrocytes. Rheumatology. 2011 May; 50(5):838-51.

9. Goldring MB. Osteoarthritis and cartilage: the role of cytokines Curr Rheumatol Rep. 2000 Dec;2(6):459-65.

10. Kapoor M, Martel-Pelletier J, Lajeunesse D, Pelletier JP, Fahmi H. Role of proinflammatory cytokines in the pathophysiology of osteoarthritis. Nat Rev Rheumatol. 2011 Jan;7(1):33-42.

11. Goldring MB, Berenbaum F. The regulation of chondrocyte function by proinflammatory mediators: prostaglandins and nitric oxide. Clin Orthop Relat Res. 2004 Oct;(427 Suppl): S37-46.

12. Berenbaum F. Diabetes-induced osteoarthritis: from a new paradigm to a new phenotype. Ann Rheum Dis. 2011 Aug; 70(8):1354-6.

13. Majjad A, Errahali Y, Toufik H, Djossou YH, Ghassem MA, Kasouati J and Maghraoui AEl. Musculoskeletal Disorders in Patients with Diabetes Mellitus: A Cross-Sectional Study. international Journal of Rheumatology, Volume 2018, Article ID3839872, 6 pages https://doi.org/10.1155/2018/3839872

14. Cho N, Shaw JE, Karuranga S, Huang Y, da Rocha Fernandes JD, Ohlrogge AW, Malanda B. IDF Diabetes Atlas: Global estimates of diabetes prevalence for 2017 and projections for 2045. Diabetes Res Clin Pract. 2018 Apr;138:271-281.

15. Mabey T, Honsawek S. Cytokines as biochemical markers for knee osteoarthritis World J Orthop. 2015 Jan;6(1):95-105.

16. Orlowsky EW, Kraus VB. The Role of Innate Immunity in Osteoarthritis: When Our First Line of Defense Goes On the Offensive. The Journal of Rheumatology. 2015 Mar;42 (3):363-71

17. King $\mathrm{KB}$, Rosenthal $\mathrm{AK}$. The adverse effects of diabetes on osteoarthritis: update on clinical evidence and molecular mechanisms. Osteoarthritis and Cartilage. 2015 Mar;2:841-850.

18. Larkin ME, Barnie A, Braffett BH, Cleary PA, Diminick L, Harth J, et all. Musculoskeletal complications in type 1 diabetes. Diabetes Care. 2014 Jul;37(7):1863-9.

19. Rosenbloom A. Periarticular Hand Joint Limitation Syndromes in Diabetes. Endocrine Practice. 2014 June; 20(8):1-14.

(Надійшла до редакиії 06.02.2019 р.) 
Оригінальні дослідження

\section{Уровень провоспалительных цитокинов в сыворотке крови больных сахарным диабетом 1-го и 2-го типов с диабетической артропатией}

\section{В.Л. Орленко}

ГУ «Институт эндокринологии и обмена веществ им. В.П. Комиссаренко НАМН Украины»

Резюме. Поражение суставов у больных сахарным диабетом (СД) является распространенным осложнением и связано с возникновением дегенеративно-дистрофических изменений в околосуставных структурах. Цель работы - изучить уровень провоспалительных цитокинов у больных с диабетической артропатией и их возможное влияние на развитие этого осложнения. Материал и методы. Обследованы 118 пациентов, которых разделили на группы по типу диабета, наличию и степени диабетической артропатии. Уровни цитокинов в сыворотке крови определяли иммуноферментным методом. Результаты. У пациентов с диабетической артропатией достоверно повышены уровни ФНО-а (при СД1 - на 44,5\%, при СД2 - на 42,9\%) и ИЛ-6 (при СД1 - на 52,1\%, при СД2 - на 64,4\%). Выявлена прямая корреляционная связь между степенью поражения суставов и уровнями ФНО-а и ИЛ-6. Для ИЛ-1, S ИЛ-6R такой связи не выявили. Выводы. Риск развития артропатии при СД1 с повышением уровня ФНО-а возрастает в 1,7 раза, с повышением показателя ИЛ-6 - в 1,5 раза, при СД2 - в 1,8 раза и 1,3 раза соответственно. ФНО-а и ИЛ-6 могут быть маркерами наличия и прогрессирования артропатии у больных сахарным диабетом.

Ключевые слова: сахарный диабет, диабетическая артропатия, суставы, хондроциты, цитокины.

\section{Level of proinflammatory cytokines in serum of patients with diabetes mellitus type 1 and type 2 with diabetic arthropathy}

\section{V.L. Orlenko}

SI «V.P. Komisarenko Institute of Endocrinology and Metabolism NAMS of Ukraine»

Abstract. Joint damage in patients with diabetes mellitus (DM) is a common complication and is associated with the appearance of intraperitoneal-dystopic changes in the periosteal structures. The aim of our work was to study the level of proinflammatory cytokines in patients with diabetic arthropathy and to investigate their possible effect on the development of this complication. Material and methods. 118 patients were examined, which were divided into groups by type of diabetes, the presence and severity of diabetic arthropathy. The content of IL-1, TNF- $a$, IL-6 and receptors to S IL-6R in serum was determined by immunoassay. Results. In patients with diabetic arthropathy, levels of TNF-a (with type 1 diabetes 44.5\%, type 2 diabetes $42.9 \%$ ) and IЛ-6 (with type 1 diabetes $52.1 \%$, with diabetes 2 types by $64.4 \%$ ) significantly increased. There is a direct correlation between the severity of joint damage and the level of TNF- $a$ and IL-6. For IL-1, receptors for S IL-6R have not been detected. Conclusions. The chances of detecting arthropathy with type 1 diabetes with increasing TNF levels increase by 1.7 times, with an increase in IL-6 by 1.5 times. For type 2 diabetes, it is 1.8 and 1.3 times, respectively. Thus, TNF- $a$ and IL-6 may be markers of the presence and progression of arthropathy in patients with diabetes mellitus

Keywords: diabetes mellitus, diabetic arthropathy, joints, chondrocytes, cytokines. 